\title{
David i fortællingen i verden
}

\author{
En spatial nuancering
}

\author{
Cand.mag. \\ Trine Bjørnung Hasselbalch
}

\begin{abstract}
Interpretations of the narratives about David in the Books of Samuel can be divided roughly into works that understand them one way or the other as products of history, and works that tend to disregard questions about their historical conditions. But neither strategy - studying the meaning of their production in terms of history, or not at all - can bring out all facets in the meaning of producing these narratives. Here a spatial approach is taken, according to which the production of literature is not simply caused by historical contexts that can be accounted for in research; it takes place in unresolved social situations of which the authors are not in control. From this perspective, some nuances are suggested about how the writing of the David narratives could be meaningful to their author(s).
\end{abstract}

Keywords: History - Spatiality - Production of meaning - King David - Books of Samuel

Det er nok ikke helt forkert at påstå om moderne bibelvidenskab, at den lider af historie-mani, eller hvad Michel Foucault har karakteriseret som "the great obsession of the nineteenth century." Moderne bibelforskning udviklede sig som en historisk-kritisk disciplin, og den gammeltestamentlige forskning er fremdeles overvejende temporalt og historisk orienteret, når den undersøger bibelteksternes fremkomst og betydning i deres antikke kontekster. Det kommer til udtryk ikke mindst i studier af store, sammensatte tekstkorpora, såsom Pentateuken eller Det Deuteronomistiske Historieværk, idet hvert lag ses som et forfatter- eller redaktorstyret skridt i en bestemt retning hver gang ud fra en betragtning om hvor det pågældende lag hører hjemme i Bibelens tilblivelseshistorie. Selvmodsigelser og ujævnheder i store og komplekse bibeltekster forklares temporalt som resultater af relativt velafgrænsede historiske problemstillinger og processer. De

1. Michel Foucault, "Of Other Spaces," Diacritics 16/1 (1986), 22-27. 
seneste par årtier har en interesse for det rumlige, eller spatiale, indfundet sig i humanvidenskaberne. Interessen for det spatiale er en interesse for kulturel hybriditet, for sidestilling af, og forhandlinger om, forskellige livserfaringer, og for de udtryk det giver, eksempelvis i kunst, litteratur og arkitektur. ${ }^{2}$ Som en foreløbig beskrivelse af, hvad jeg forstår med spatialitet, vil jeg citere antropologen Tim Ingold, som selv undviger begrebet, men alligevel koncist indkredser fortallingen som spatialt virke:

To tell, in short, is not to represent the world but to trace a path through it that others can follow. Of course, anthropologists have long recognized the educative functions of storytelling among people the world over. But they have been wrong to treat stories as vehicles for the intergenerational transmission of encoded messages that, once deciphered, would reveal an all-embracing system of conceptual categories. ${ }^{3}$

I overført betydning er det at digte og skrive fortællinger det samme som at betræde nyt land og sætte sig spor, at skabe nye stier og bevægelsesmønstre. Man kan skelne mellem to tilgange til det at finde mening i bibelteksterne i den gammeltestamentlige forskning: i den ene holdes fokus på bibelfortællingernes tilblivelseskontekster som historisk, meningsforklarende kontekst, i den anden på den mening som opstår i mødet mellem tekst og læser.

Men der er en tredje form for mening, som sjældnere berøres i bibelforskningen, og som jeg vil forsøge at nærme mig her. Det er en mening, som ikke er at finde i forfatternes intentioner om at aflevere (og få optaget) et bestemt budskab, sådan som de viser sig i teksten, og heller ikke kan aflæses i dens senere brugs- og fortolkningssituationer. Det, jeg tænker på, er meningen i processen med at frembringe en fortælling. Det handler om fortællekunst og tekstproduktion som social proces og som redskab til at orientere sig i verden. Ved at tænke spatialt vil jeg forsøge at nærme mig denne form for mening i fortællingerne om David (primært 2 Sam 9-20). Men først et blik på velkendte ikke-spatiale fortolkninger og fortolkningsstrategier og på nogle centrale punkter fra spatialitetsteorien.

2. Henri Lefebvre, The Production of Space (Oxford: Blackwell 1984); Homi Bhabha, The Location of Culture (London: Routledge 1994); Edward Soja, Thirdspace. Journeys to Los Angeles and Other Real-and-imagined Places (Oxford: Blackwell 1996); Peter Burke, Cultural Hybridity (Cambridge: Polity Press 2009). Eksempler fra bibelrelateret forskning: Liv Ingeborg Lied, The Other Lands of Israel. Imaginations of the Land in 2 Baruch (Leiden: Brill 2007); Karen Wenell, Jesus and Land. Sacred and Social Space in Second Temple (London: T\&T Clark 2007).

3. Tim Ingold, Being Alive. Essays on Movement, Knowledge and Description (London: Routledge 2011), 162. 


\section{Et kort rids af fortolkningsstrategier}

Forklaringer på, hvordan store, sammensatte tekstkorpora er blevet til, har traditionelt været historisk orienterede. ${ }^{4}$ Herman Gunkel, som var mere optaget af Hexateukens komponenters formhistorie, inden noget blev nedfældet på skrift, talte gerne om tilvakst, om hvordan nye elementer blev tilføjet, hvad man allerede havde for hånden gennem en form for naturlig proces. Vakst og proces er temporale begreber. Siden opstod der en historisk bevidsthed og deraf en tilskyndelse til at nedfælde de traditioner, man selv havde fået fortalt fra mund til mund på skrift og bevare for efterfølgende generationer. Der lå altså en historisk eller ligefrem historiografisk interesse bag skriftliggørelsen af traditionen. Senere opstod ideen om en forfatter, en person som ikke nøjedes med at samle materiale, men som formgav det ud fra sin egen ideologiske agenda. Hvad disse forfattere skabte, var historiske beretninger eller fortolkninger af historiske udviklingsforløb (om det så var i form af von Rads frelseshistorie eller i form af Noths negative, deuteronomistiske historie, som endte med eksilet). Efterhånden udvikledes en egentlig redaktionskritisk disciplin, hvor ideen om en forfatter langt hen ad vejen afløstes af ideen om redaktorer, som reviderede akkumulerede traditioner, harmoniserede og tilpassede dem uden egentlig at være nyskabende.

Ofte forudsættes en bestemt historisk tilblivelseskontekst for bibelske tekstdele, og de findes gennem redaktionshistoriske analyser i bibelteksten selv. Det gælder eksempelvis hele Det Deuteronomistiske Historieværk, som ifølge Martin Noth er skrevet i eksilsk tid som en forklaring på netop eksilet - en historisk begivenhed med alvorlige, samfundsmæssige konsekvenser. Dele af Samuelsbøgerne og Kongebøgerne er blevet fortolket som propagandistiske indslag i historiske kontekster, som vi kun har kendskab til netop fra denne litteratur: Således skulle beskrivelsen af Salomos halvbrødres forgæves kamp om Davids trone i 2 Sam 12,24-1 Kong 2,46 stamme fra Salomos regeringstid og agitere for netop hans legitimitet som rette arvtager til tronen. På samme vis henregnes beretningen om, hvordan profeten Samuel udså Saul til konge over Israel (1 Sam 9-10), ikke til Sauls regeringstid, men til hans efterfølgeres tid, som et forsøg på at legitimere Sauls dynasti over for Davids dynasti. ${ }^{5}$

4. For en kritisk gennemgang med særligt fokus på redaktionskritikken, se John Van Seters, The Edited Bible. The Curious History of the "Editor" in Biblical Criticism (Winona Lake, Indiana: Eisenbrauns 2006), 185-297.

5. Roger N. Whybray, The Succession Narrative. A Study of II Samuel 9-20 (London: CSM 1968), 20-21; Marc Zvi Brettler, Creation of History in Ancient Israel (London: Routledge 1998). 
To retninger inden for bibelforskningen afviger fra dette dominerende spor i den historisk kritiske forskning: For det første er der de såkaldte "minimalister," som stiller sig kritiske til, hvorvidt Bibelens såkaldt historiske dele rent faktisk er historiografiske, og afviser såvel Sauls som Davids og Salomos historicitet. Der er delte meninger, om Det Deuteronomistiske Historieværk bør dateres til persisk eller hellenistisk tid. Men der er enighed om, at fortællingerne projicerer en række fiktive begivenheder tilbage til en fælles, glorificeret fortid, "kongetiden." ${ }^{6}$ Mit udgangspunkt ligger også her, selv om minimalisterne i deres iver efter at afmontere den selvfølgelighe,d hvormed Bibelen har været betragtet som objektiv historieskrivning, kun i begrænset omfang har inddraget spatiale aspekter ved selve Bibelens tilblivelse. $^{7}$

Den anden retning, som forsøger at lægge den historisk-kritiske tilgang til side, foretager litterære læsninger, hvor vægten ligger på tekstens struktur og indre logik og på den mening, som teksten får i mødet med dens læsere, snarere end på værkets eller dets enkeltdeles historiske oprindelse. ${ }^{8}$ Her er der tale om synkrone læsninger, hvor fortolkeren accepterer, at inkongruenser og modsætninger står side om side uden at ville forklare dem som resultat af en historisk redaktions-proces. ${ }^{9}$ Ulempen med disse læsninger er deres ofte agnostiske forhold til en oprindelig mening. Idet de afviser at kende en historisk betinget forfatterintention, søger de al mening i mødet mellem teksten og dens læsere. Fokkelman sætter dette på spidsen:

6. Keith Whitelam, The Invention of Ancient Israel. The Silencing of Palestinian History (London: Routledge 1996); Niels Peter Lemche, Det Gamle Testamente mellem teologi og historie. Den historisk-kritiske bibelforsknings storhed og fald (København: Anis 2008); Thomas Thompson, The Bible in History. How Writers Create a Past (London: Jonathan Cape 1999).

7. Keith Whitelam vier eksempelvis mange sider på at fremstille bibelforskere og arkæologer som eurocentriske, fordi de har undladt at afse rum til en Palæstinensisk historie i Palæstina; problemet er både deres nomenklatur for det område som Bibelen beskriver, og tendensen til at lade ideen om en israelitisk/judæisk nationalstat $\mathrm{i}$ antikken blænde af for al interesse $\mathrm{i}$ andre folk og indbyggeres liv i området. Whitelam (1996), 39-58.

8. Robert Polzin, Moses and the Deuteronomist. A Literary Study of the Deuteronomistic History. Part One: Deuteronomy, Joshua, Judges (New York: The Seabury Press 1980); David and the Deuteronomist. A Literary Study of the Deuteronomistic History. Part Three: 2 Samuel (Bloomington: Indiana University Press 1993); David Gunn, King David. Genre and Interpretation. JSOTsup 6 (Sheffield: Sheffield University Press 1978); J.P. Fokkelman, Narrative Art and Poetry in the Books of Samuel, vol. 1 (Assen: Van Gorcum 1981); Walter Brueggemann, David's Truth in Israel's Imagination and Memory (Repr. 1985; Philadelphia: Fortress Press 1986).

9. Dog går de ikke fri af kritik for alligevel at bygge på den historisk-kritiske forsknings præmisser, når de drister sig til at medtænke en mulig historisk kontekst som baggrund for deres teksttolkninger. 
The Text appears exclusively within the horizon of the Here and Now which is created by the reader's attention. Only by virtue of being read today can anything meaningful, whatever it be, be adduced about the Bible, Sophocles, etc. Text and reader need each other just as much as form and content do, and they presume each other likewise. (Fokkelman 1981, 423)

Historiske kontekster er rigtig nok sproglige konstruktioner og refleksioner, foretaget post festum, og uagtet hvor tæt en historisk beskrivelse er i stand til at ramme noget, der har fundet sted, betragter den det stedfundne udefra og på afstand. Men det er ikke ensbetydende med, at spatiale eller rumlige oprindelseskontekster hverken kan anes eller antydes: Der er spor af det umiddelbare, uafsluttede, oplevede, mangfoldige og uoverskuelige, som mennesker har ageret i; det er noget man ikke kan definere, kun tilnærme sig og beskrive tentativt.

\section{Teorier om spatial mening}

Helt generelt prøver spatialitets-teoretikere at indfange det faktum, at mennesker, med geografen og spatialitetsteoretikeren Edward Sojas ord, er lige så meget spatiale som temporale væsener (Soja 1996, 16). Han kritiserer det, han kalder "that most historicist of epistemological fallacies: post hoc, ergo propter hoc," eller med andre ord "after this, therefore because of this" (Soja 1996, 200). Som eksempel nævner han en arkitektur-kritiker, som ville forklare den urbane fornyelse af Los Angeles, herunder nedrivningen af et centralt kvarter, med en stor andel af fattige indbyggere, som en følge af kapitalistisk ideologi, fordi man ønskede at gøre plads til "the shining monuments of global capitalism.” Men sådan en forklaringsmåde er ifølge Soja problematisk, fordi den ensidigt gør den globale kapitalisme og dens narrative plot til årsagen bag en bestemt byudvikling. Soja ville i stedet have foretrukket en forklaringsmåde med plads til "lateral and synchronic connections" og til postmoderne udfordringer af det, han kalder kapitalismens (og andre -ismers) radikale diskurs og politik (Soja 1996, 199-201). Soja mener med andre ord ikke, man bør gøre en ideologi eller et bestemt tankesæt til en forudsætning for hverken bygningsværk eller andre kulturelle produkter - og sådan et synspunkt må farve analysen.

Teoretisk bygger Soja på tre spatialitets-kategorier udarbejdet af Henri Lefebvre:

- Firstspace: typisk fysiske, målelige rum - spatialitet som vi oplever det omkring os i dagligdagen. 
- Secondspace: rummelighed intellektuelt opfattet ("conceived space”) og repræsenteret som kunstneriske eller filosofiske ideer ("Representations of space"). Secondspace fremstår ofte som binar ("binaristic"); det, der udtrykkes, er en idé og dens modsætning, og ethvert forhold betegnes ud fra i forvejen kendte kategorier, men dette er ifølge Lefebvre en reduktionisme.

- Thirdspace: levet rumlighed ("lived spaces of Representation"/ 'Representational spaces') som indebærer en radikal åbnen op, hvor måder og muligheder kan lægges til det allerede kendte og eksemplificeres gennem levet liv, det simultane og gentagelsen.

Det er Thirdspace, som skal udfoldes her. I Thirdspace er kroppen altid både objekt og subjekt. Derfor er det inden for rammerne af Thirdspace umuligt at indtage en fuldt ud objektivistisk stillingtagen til ting.

Det må have konsekvenser for analysen af tekster - også store og komplekse tekster betragtet som produkter af historiske processer når vi iagttager, at de producerer og udfolder Thirdspace. Det er da nødvendigt ikke at se det skrevne primært som repræsentation, men at forstå det at skrive som en praksis, indfældet hos de skrivende, som en del af deres livsudfoldelse. Der er en tendens blandt eksegeter (og andre læsere) til at se bibelske og andre skrifter som afsluttede produkter, endelige repræsentationer af noget - en hændelse, en idé, en ideologi. Men dette er nok i virkeligheden at reducere det skrevnes mening, set i forhold til den mening det har haft for nogen at skrive det.

Selv tøvede Lefebvre med at tro tekster kunne udfolde og skabe Thirdspace på samme måde som performance-kunstarter, fordi tekster til sammenligning syntes at tilhøre den mentale sfære: Det skrevne iscenesættes jo ikke i skriveprocessen på samme måde som eksempelvis dans, musikudøvelse, skulptur, og arkitektur, for det mangler den fysiske manifestation.

Soja griber fat i forskellen, men bortforklarer den nærmest som et resultat af visse begrænsninger iboende al skrivning, såsom at diskursive medier nødvendigvis må repræsentere ideer, hændelser, erfaringer etc. sekventielt - og dette sker da på bekostning af samtidigheden mellem elementer eller momenter i et værk. Tilsyneladende mener Soja, at det er muligt at overkomme begrænsningerne, idet han foreslår, at Lefebvre selv realiserede den rumlige samtidighed i sin måde at skrive på: Soja sammenligner Lefebvres bog The Production of Space med polyfoniske musikalske værker, som ved hjælp af kontrapunktiske strukturer konstrueres som gentagelse og variation (Soja 1996, 8-9; 58). The Production of Space er således: 
...itself a text, a sequential narrative subjective to all the constraints of language and writing and, still further, to the unexpected aporia arising from its translation from French to English. It too is a 'reading' rather than an 'inhabiting,' a 'discourse' rather than a practical 'knowledge' of space. Lefebvre had to contend with the successive constraints of writing about simultaneities, about the repetitive and the differential, the known and the unknowable, at the same time (Soja 1996, 58).

Litteratur- og spatialitetsteoretikeren Homi Bhabha giver et mere direkte udtryk for skrivningens produktive kraft: Han mener ikke, at politisk teori (og udpræget ideologiske tekster) adskiller sig væsentligt fra politisk handling. Både teori og aktivisme er diskursive former, og som sådanne "producerer de snarere end de reflekterer deres referenceobjekter." 10

Ifølge Bhabha skrives der ikke ud fra fasttømrede positioner, og skrivningen repræsenterer ikke et endeligt, ideologisk standpunkt: "Textuality is not simply a second-order ideological expression or verbal symptom of a pre-given political subject." Skrivningen er snarere selv "a productive matrix which defines the 'social' and makes it available as an objective of and for, action." Det sociale rum er med andre ord aldrig en given ting, men formgives uafladeligt gennem verbale og non-verbale udtryk for forhandling (Bhabha 1994, 23; Ingold 2011, 157-59).

Ideologi præsenteres altid i en form for historisk medias res, og står altid over for konkurrerende positioner og intentioner. Ideologiske repræsentationer er faktisk heterogene og forhandlende. En hvilket som helst politisk kamp, også bestræbelsen på at fastholde et hegemoni, er ifølge Bhabha en iterativ og differentieret proces, som afhænger af "the production of alternative or antagonistic images that are always produced side by side and in competition with each other." (Bhabha 1994, 29).

Det virker oplagt, at vi vil kunne få en bedre forståelse af store, sammensatte tekstkorpora, som ellers analyseres redaktionskritisk, hvis vi anlægger et synkront perspektiv og betragter de "redaktionelle lag" som spor af de iterative og differentierede processer, som Bhabha omtaler; de anskues da ikke som manifestationer af hverken faste ideologiske positioner eller faktuelle hændelser i løbet af et historisk tidsforløb, men snarere som elementer af en stræben efter at frembringe og definere sociale rum og grænser.

10. Bhabha (1996), 21-22: "and to that extent they produce rather than reflect their object of reference." 


\section{Spatialitet i litteraturen}

Litteraturteoretikeren Mikhail Bakhtin, som næppe kan kaldes spatialitetsteoretiker som sådan, tilskriver litteraturen en betydning tæt på den, som de nævnte spatialitetsteoretikere tilskriver kunstneriske udtryk, herunder, som beskrevet, litteraturen. Bakhtin introducerede begrebet kronotop til at beskrive forholdet mellem litteratur og virkelighed, mellem det skrevne på den ene side, og den tid og det rum, som det er skrevet i og omhandler, på den anden. ${ }^{11}$ Grundlæggende mener Bakhtin, at et samfund udtrykker forhold der gælder dets samtid og fremtid i form af fortællinger fra fortiden: “...mythological and artistic thinking locates such categories as purpose, ideal, justice, perfection, the harmonious condition of man and society and the like in the past," og han fortsætter:

Myths about Paradise, a Golden Age, a heroic age, an ancient truth, as well as the later concepts of a 'state of nature,' of natural, innate rights and so on, are all expressions of this historical inversion. To put this in somewhat simplified terms, we might say that a thing that could and in fact must only be expressed exclusively in the future is here portrayed as something out of the past, a thing that is in no sense part of the past's reality, but a thing that is in its essence a purpose, an obligation (Bakhtin 1981, 147).

En fortælling fremstår som afsluttet - den har en begyndelse og en afslutning - men af citatet fremgår det, at roman-fortællingen for Bakhtin handler om det endnu uafsluttede, om fortællerens samtid og den usikre fremtid. Her er vi tilbage ved det spatiales vilkår, herunder at en forfatter ikke er en objektiv betragter, men en der producerer snarere end repræsenterer virkeligheden. Den færdige fortælling må spejle den ufærdige virkelighed, den omhandler.

\section{Test Case: David i fortællingen i verden}

I forskningsoversigten har jeg beskrevet, hvordan Thirdspace udfolder sig i litteraturen og andre kunstarter, men uden at berøre specifikt den konkrete, rumlige oplevelse. Men det er klart at også litteraturen forholder sig til og behandler fysiske rum, som forfattere kender til - steder og landskaber, hvor de har været til stede, levet, været på gen-

11. Mikhail Bakhtin, "The Chronotope" i The Dialogic Imagination. University of Texas Press Slavic Series, 1 (Transl.; Austin: University of Texas Press, 1981), 84. Her beskriver Bakhtin kronotopen som "the intrinsic connectedness of temporal and spatial relationships that are artistically expressed in literature." 
nemrejse. De har haft visse opfattelser af disse rum, om hvem der har befolket dem, hvordan man har kunnet leve der og tjene til livets ophold, hvem der har haft magten, osv. Det gælder også fortællingerne om David, og i den kortfattede case, hvor jeg nu vil forsøge at vise, hvad en spatialt orienteret analyse kan bibringe, vil jeg tage udgangspunkt netop i et konkret rum som manifesterer sig i fortællingerne.

Fortællingen om kong David er også en fortælling om et landskab, men selv om forfatterne nok "låner" fra både selverhvervede erfaringer og forestillinger om dette landskab, fremmaner fortællingen noget helt tredje - et Thirdspace. I den historisk-kritiske forskning behandles de landskaber og begivenheder der fortælles om, ofte som Secondspace, som måder at forholde sig til og forhandle i rum behersket af fælles begrebsdannelse og videns-klassificering, herunder om hvilke ideologier og positioner der gør sig gældende. Det er et rum, hvor der argumenteres og demonstreres med henblik på at flytte positioner og ændre magtbalancer.

Den redaktionskritiske forskning beskæftiger sig med Secondspace, når den udskiller redaktionshistoriske lag, hvis logik og retoriske formål den udlægger som ret entydige og indlysende ud fra specifikt definerede, historisk kontekster. Men nu er forudsætningen at der aldrig eksisterede et israelitisk/judæisk kongedømme i Palæstina, så vidt udstrakt og mægtigt, som det man finder i Samuelsbøgerne og Kongebøgerne. Derfor giver det ikke mening at se de "historiske" forhold der fortælles om, som retoriske situationer bagved fortællingerne om de geografiske områder kaldet Israel og Judæa. Omdrejningspunktet må findes et andet sted.

\section{Samuelsbøgernes landskab}

I Samuelsbøgernes fremstilling bliver Israel og Judæa forenet i et dobbelt kongedømme under David med kongesæde i Jerusalem. Når arken, som ellers har fulgt et nomadisk bevægelsesmønster, făr permanent ophold der (2 Sam 6), viser det, at Davids kongedømme lever op til en "global" norm for, at en nation har én samlende guddom. ${ }^{12}$ Generelt rummer fortællingerne om David og hans land mange informationer om baser, rejser, troppebevægelser etc., der bidrager til at give indtryk af et område og dets jurisdiktion. Jeg vil fokusere på et aspekt ved dette, nemlig områdets afgrænsning i øst, langs Jordan, som spiller en central rolle i Jeremy Huttons analyse af det, han betegner som den Transjordanske Palimpsest i Det Deuteronomistiske

12. Mark S. Smith, God in Translation. Deities in Cross-Cultural Discourse in the Biblical World (Grand Rapids: Eerdmans 2010), 157-63. 
Historieværk. ${ }^{13}$ Hutton fokuserer på Cisjordan og Transjordan, og på betydningen af at krydse Jordanfloden i denne litteratur. På forskellige niveauer - som også tilhører forskellige redaktionelle lag - har det en særlig betydning at krydse (eller bade i) Jordanfloden. Jordanfloden bliver i Huttons læsninger et polysemisk tegn, som rummer forskellige typer af meninger i de forskellige perikoper eller fortællinger: Tegnets funktion kan være pragmatisk, som i fortællingen om Gideons ophold i Transjordan (Dom 8), fordi hans militære sejr der er en forudsætning for hans senere militære sejr og position i Israel. Den kan også have en symbolsk og liminal betydning, som når Davids ophold i Mahanajim (2 Sam 15-17) bliver en form for metafysisk intervention og forberedelse til hans genvindelse af kongemagten. Den kan være metaforisk, hvilket gælder Naamans badning i Jordan (2 Kong 5), idet to livsforhold, badning i almindelighed og rituel, kultisk renselse, sammenlignes i denne scene.

Den overordnede logik i Transjordan som polysemisk tegn finder Hutton ved at læse perikoperne $i$ lyset af hinanden: Transjordan er et eksil- og tilflugssted. Et sted hvor metamorfoser finder sted og gør individer $\mathrm{i}$ stand til at indtage magtfulde positioner i Israel (Hutton 2006, 5). Det gælder flere af de figurer, som optræder i hoffortællingerne (eller tronfølgefortællingerne): Sauls søn Ishboshet blev bragt over til Mahanajim og siden gjort til konge over Israel. Absalom flygtede til Geshur (2 Sam 13:38; 15), og selvom han efter sin tilbagekomst, som David foranlediger, får svært ved at nærme sig hoffet, giver opholdet i Jerusalem ham muligheden for at forberede et oprør mod sin far kongen. Kong David selv bliver på grund af Absaloms oprør nødsaget til at flygte til Mahanajim, men da han vender tilbage fra det transjordanske, sejrer han over sønnen og genvinder magten og legitimiteten, som han beholder indtil sin død.

Når Hutton sammenfatter relationen mellem alle disse fortællinger og perikoper i den transjordanske palimpsest og den endelige redaktion af dem i Det Deuteronomistiske Historieværk, understreger han ,at sidstnævnte, med brug af eksisterende, meningsfulde tegnsæt, udgjorde "a single developing symbolic system," og at dette system af fortællinger efter eksilet ville indgyde det judæiske samfund den optimisme, som præger Deuterojesaja (Hutton 2006, 376-377). Fortolkningen ser altså det (nyligt) tilbagelagte eksil som historisk bagtæppe. Med den forudsætning fastholder Hutton sin overordnet set optimistiske fortolkning af den transjordanske palimpsest, selvom han understreger, både at det judæiske samfund, som færdedes i landskabet,

13. Jeremy Hutton, The Transjordanian Palimpsest. The Overwritten Texts of Personal Exile and Transformation in the Deuteronomistic History. BZAW (Berlin: De Gruyter 2006). 
på intet tidspunkt var en monolitiske størrelse (Hutton 2006, 35-37), og at grundlaget for optimismen i teksten selv ikke er entydigt (Hutton 2006, 373): Efter at Ishboshet er blevet konge over Israel, rykker han ud mod David med tab og bliver siden myrdet (2 Sam 2, 8-9; 4, 4-7). Absalom, som nok overtager kongemagten fra David for en tid, ender med at blive dræbt (2 Sam 18, 9-17), og netop Absaloms død gør, at også Davids sejr og indtagelse af det dobbelte kongerige bliver en Pyrrhussejr, for tabet af sønnen er et tungt slag (2 Sam 19, 1). Det at vende tilbage fra et ophold i Transjordanien garanterer altså ikke en ubetinget succes. Dette kan sammenholdes med, at Det Deuteronomistiske Historieværk i sin helhed fremstår pessimistisk i synet på kongedømmets skæbne: det ender i opløsning, og selve kongemagten har en stor lod i denne deroute. Både denne overordnede bevægelse i Det Deuteronomistiske Historieværk og detaljer i den transjordanske palimpsest sår tvivl om det rigtige $\mathrm{i}$ at betone en rendyrket optimisme på vegne af det post-eksilske samfund.

Pointen er, at der er en vis tvetydighed. David (og ganske få andre konger) fremstilles i positivt lys, sammenlignet med den lange række af konger, som før eller siden skuffer enhver positiv forventning til dem. Men også Davidskikkelsen er tvetydig (ikke mindst i kraft af episoderne med Batseba og Urias).

\section{Fortællingens tvetydigheds kerne}

Thomas Thompson fortolker denne tvetydighed som en del af en helt særlig konstruktion: Han daterer de bibelske fortællinger om David i deres foreliggende form til hasmonæisk tid, det tidspunkt hvor der for første gang fandtes en judæisk kongemagt af betydning i Palæstina. Tiden var præget af, hvad Thompson kalder sekteriske bevægelser, der hver især så sig selv som det såkaldt "nye Israel." I deres optik repræsenterede skriftens fortællinger om kongetiden det faldne "gamle Israel," men i virkeligheden var både kongetiden og det totale eksil en konstruktion og en retorisk platform for forskellige gruppers påstande om legitimitet som det "nye Israel."14 Davidfiguren var ikke mindst et fromhedsideal for medlemmer af dette Israel, for en af denne mytes væsentlige funktioner var ifølge Thompson den didaktiske at opdrage publikum ud fra et bestemt værdisæt, hvilket bliver tydeligt i Salmernes Bog: "As David's purity of heart in the story tradition determined the fate of his house and his people, the

14. Thomas L. Thompson, The Mythic Past. Biblical Archaeology and the Myth of Israel (London: Random House 1999), 207-210. 
idealized David of the Psalter provides the pious with their role as David's house and people."15

Groft sagt ser det ud til at tvetydigheden for Thompson skyldes, at forfatterne har haft to grundlæggende intentioner: at eksemplificere en fromhedsnorm og at skabe en kontrast til andre gruppers opfyldelse af normen - noget at identificere sig fra. Ud fra en spatial betragtning bifalder jeg synet på David som fromhedsideal, men tvivler på ideen om, at historieværket skulle være formgivet med tanke på at lægge afstand til beslægtede subkulturer. Det er en forklaringsmodel, som ser konstruktionen af det stærke dobbeltmonarki som et produkt af en færdigudviklet idé og et klart formål om, hvad man ønsker at opnå. Det er en fortolkning foretaget i Secondspace.

Jeg vil derfor forsøge at nuancere denne forklaringsmodel ud fra en spatial tankegang. Empirisk er udgangspunktet, at vi har at gøre med en konstruktion; teoretisk at konstruktionen og teksterne kan være aktivistiske, men ikke nødvendigvis ud fra et færdigudviklet ideologisk standpunkt. Inspireret af Ingold vil jeg derfor beskrive konstruktionen af det davidiske kongedømme som et forsøg på at træde nye veje: projektet er behæftet med usikkerhed. Hvad kan det ellers være, at fremmane et stærkt kongedømme i folks historiske bevidsthed, hvor der intet sådant var i forvejen?

David Gunn er inde på noget af dette, når han kritiserer den gængse afgrænsning af en såkaldt tronfølgefortælling i 2 Sam 9-20 samt 1 Kong 1-2. Han mener i stedet, at fortællingen strækker sig allerede fra 2 Sam 2-4 og handler om noget ganske andet end hvilken søn, der skal efterfølge David på tronen, nemlig kong David selv. ${ }^{16}$ Spørgsmålet for Gunn er, om David overhovedet vil lykkes med at etablere et dynasti (Gunn 1978, 82). Når der viser sig sprækker i Davids psykiske konstellation (som når han ved meddelelsen om Absaloms død går fra at fremtræde som konge til at fremtræde som menneske - eller når han træder ved siden af med Batseba og ser til at få Urias dræbt), er det med til at så tvivl om det projekt - til trods for at David var Herrens udvalgte.

Tvetydigheden i Davids skikkelse svarer således til en tvetydighed i kongemagten, og jeg tror, at de to viser to sider af samme sag, nemlig et træk ved et samfund eller en social gruppe som var i stand til at identificere sig med begge dele på en gang: Fortællingens tvetydighed indekserer oplevelsen af at tilhøre en gruppe, en subkultur, om man vil, som muligvis manglede en fasttømret institutionel ramme endnu, og hvis fremtidsudsigter var usikre. Det Deuteronomistiske Hi-

15. Thomas L. Thompson, The Messiah Myth. The Near Eastern Roots of Jesus and David (New York: Basic Books 2005), 316. Se også The Mythic Past, 52-55.

16. Jf. titlen på Gunns bog: The Story of King David. 
storieværk lader som bekendt det davidiske dynasti ende i opløsning, og vejen frem er en i store træk dysfunktionel kongerække, gang på gang ude af stand til at leve op til lovens pagt.

Men hvordan kunne det give mening for dette samfund at identificere sig som et kongedømme på niveau med reelle politiske magter i omverdenen, hvis det hverken stemte overens med historiske realiteter eller underbyggede et positivt selvbillede? Hver på sin måde billedliggør både David og hans dynasti en skrøbelighed, en usikkerhed om evnen til at leve op til det af Gud opstillede ideal. Ud fra det perspektiv, at litteratur, som andre kulturudtryk, tager form i Thirdspace, giver jeg Gunn ret i hans udsagn om fremstillingen af kong David: "This is the work of no propagandist pamphleteer nor moralizing teacher: the vision is artistic, the author, above all, a fine teller of tales" (Gunn 1978, 111). Men det er ikke ensbetydende med, at fortællingen ikke er tæt forbundet med skabelseskonteksten. Fortællingerne er hellige i den forstand, at de viser nogle iboende træk ved et kollektiv og dets identitet. Det, fortællingen indkapsler og videregiver, er dette kollektivs uigennemsigtige kerne som er hellig i den forstand, at den konstituerer gruppen, men som uden fortællingen forbliver utilgængelige. ${ }^{17}$ Fortællingen rører altså ved samfundets kerne og har ikke sin eneste berettigelse i det instrumentelle, det at skabe kontrast til andre synsmåder og andre identitets-fællesskaber.

\section{Et efterliv i Thirdspace}

Når det er sagt, kunne Det Deuteronomistiske Historieværks fortælling om David gøres til et instrument for politiske aspirationer. For den fremmaner visionen af et geo-politisk rum i Palæstina, hvor israelitter og judæere, eller jøder, var herrer i eget hus. Selvom fortællingen, sådan som fortællinger typisk gør, umiddelbart fremstår temporalt og historisk fokuseret, er den spatial, fordi den skaber nye rum for politisk handling. Med Bhabhas ord producerer den, snarere end den reflekterer, sit referenceobjekt. Sådan gik det til, at David også blev et indeks for Israel som en territorial magt. En spæd begyndelse ligger i Krønikebøgernes udelt positive fremstilling af David. Første Makkabæerbog låner mange vendinger brugt om David i Samuelsbøgerne til at beskrive de makkabæiske helte - men med den lille

17. Bernhard Giesen, "Performing the Sacred: a Durkhemian Perspective on the Performative Turn in the Social Sciences," in Giesen, Alexander and Mast (eds.), Social Performance. Symbolic Action, Cultural Pragmatics, and Ritual (Cambridge: Cambridge University Press 2006), 325-367. 
twist $\mathrm{i}$ at de gives et tydeligt glorificerende skær. ${ }^{18}$ Det er også svært at forestille sig realiseringen af den moderne, demokratiske stat Israel uden Bibelens fortælling om David og hans kongedømme, men den har måske også arvet noget af den tvetydighed som er indlejret i det deuteronomistiske fortælleværk. Men det er en anden historie.

18. Martha Himmelfarb, "'He Was Renowned to the Ends of the Earth' (1 Maccabees 3:9). Judaism and Hellenism in 1 Maccabees," Literatures and Cultures: Context and Intertext red. A. Norich and Y. Z. Eliav, (Atlanta: Society of Biblical Literature 2008), 77-97. 